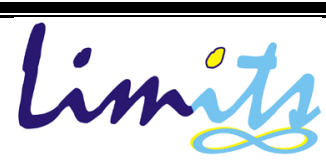

Limits: Journal of Mathematics and Its Applications

E-ISSN: 2579-8936

P-ISSN: 1829-605X

Vol. 18, No. 2, Nopember 2021, 155-167

DOI: http://dx.doi.org/10.12962/limits.v18i2.8297

\title{
Penentuan Nilai Awal Iterasi pada Masalah Pendugaan Parameter Regresi Taklinier
}

\author{
Mohammad Jamhuri ${ }^{1,2}$, Subiono ${ }^{1}$ \\ ${ }^{1}$ Departemen Matematika Fakultas Sains dan Analitika Data, ITS Surabaya Indonesia \\ ${ }^{2}$ Jurusan Matematika Fakultas Sains dan Teknologi, UIN Maulana Malik Ibrahim Malang Indonesia \\ e-mail:m.jamhuri@live.com¹, subiono2008@matematika.its.ac.id ${ }^{2}$
}

Diajukan: 31 Desember 2020, Diperbaiki: 27 Mei 2021, Diterima: 6 September 2021

\begin{abstract}
Abstrak
Paper ini membahas tentang pendugaan parameter model regresi tak linier menggunakan metode Newton, Gauss-Newton, steepest descent, dan homotopi. Metode-metode tersebut tidak senantiasa dapat memberikan hasil sebagaimana yang diharapkan, sebab hasil yang diperoleh sangat bergantung pada nilai awal yang diberikan. Keberhasilan metode-metode tersebut juga tidak ditentukan oleh seberapa dekat nilai awal terhadap solusi yang diharapkan, tetapi lebih kepada berhingga atau tidaknya elemen-eleman matrik Jacobi dari hampiran sistem persamaan tak liniernya. Selanjutnya, nilai awal diperoleh dengan cara membangkitkan bilangan random pada rentang tertentu dan dipilih yang dapat menghasilkan matriks Jacobi dengan elemen-elemen berhingga.

Kata Kunci: regresi tak linier, metode Newton, Gauss-Newton, steepest descent, homotopi.

Abstract

This paper discusses the estimation of nonlinear regression model parameters using Newton, GaussNewton, steepest descent, and homotopy methods. These methods do not always produce the expected results because they depend on the given initial values. The success of these methods is not determined by the proximity of the initial value to the expected solution but determined by whether the elements of the Jacobian matrix obtained from the approximation of the system of nonlinear equations are finite or not. Furthermore, the initial value is obtained by generating random numbers in a specific range and selecting a Jacobian matrix with finite elements.
\end{abstract}

Keywords: non-linear regression, Newton method, Gauss-Newton, steepest descent, homotopy.

\section{Pendahuluan}

Persamaan regresi secara umum dapat dituliskan sebagai

$$
y=f(x ; \theta)+\epsilon
$$

dengan $y$ merupakan variabel respon dari data $x=\left(x_{1}, \ldots, x_{m}\right)$, sedangkan $\theta=\left(\theta_{1}, \ldots, \theta_{p}\right)$ adalah parameter-parameter regresi yang harus ditentukan. Fungsi $f$ dalam persamaan (1) disebut sebagai fungsi regresi, dan dikatakan linier jika $f$ linier terhadap $\theta$ dan taklinier jika sebaliknya. Pembahasan terkait pendugaan parameter model linier sudah dianggap cukup lengkap dan tidak 
terlalu ada masalah lagi, sebaliknya untuk model taklinier masih banyak masalah yang belum dapat diselesaikan [1].

Masalah utama dalam metode-metode penyelesaian tak linier adalah bagaimana memilih nilai tebakan awal yang baik untuk suatu iterasi. Nilai awal yang sudah ditentukan dapat menyebabkan iterasi akhir menjauhi atau mendekati solusi yang diharapkan. Nilai awal dengan iterasi akhir mendekati solusi merupakan masalah yang masih terbuka untuk diteliti sampai saat ini [2].

Untuk fungsi dengan satu peubah, pemilihan nilai awal dapat dilakukan dengan cara menggambar fungsinya terlebih dahulu, kemudian dapat diperkirakan secara grafik letak akar atau solusinya, tetapi untuk fungsi dengan lebih dari dua peubah, hal ini sulit untuk dilakukan. Beberapa penulis menyarankan penggunaan metode steepest descent, homotopi, atau metode-metode dengan tingkat konvergensi rendah lainnya sebagai metode awal untuk memilih tebakan awal [2], [3]. Metode-metode dengan tingkat konvergensi rendah dikenal lambat dalam mendekati solusi, tetapi dapat memberikan hasil yang baik meskipun nilai tebakan awal yang diberikan cukup jauh dari solusi sebenarnya [4].

Metode Newton dan Gauss-Newton adalah metode-metode iterasi yang juga membutuhkan nilai tebakan awal untuk memulai iterasi. Kedua metode sama-sama menggunakan deret Taylor sebagai pendekatan terhadap fungsi regresinya. Perbedaan antara keduanya terletak pada bagaimana pendekatan linier dilakukan terhadap fungsi regresinya. Pada metode Gauss-Newton, pendekatan linier terhadap fungsi dilakukan di awal, yaitu dengan mengubah fungsi regresinya dengan fungsi pendekatan linier menggunakan deret Taylor [4], [5]. Sedangkan pada metode Newton, pendekatan linier dilakukan pada penyelesaian sistem yang diperoleh dari proses meminimalkan jumlah kuadrat eror model regresinya [6].

Dalam pembahasan, terlebih dahulu akan diberikan contoh-contoh pendugaan model regresi tak linier dengan dua parameter menggunakan metode Newton dan metode Gauss-Newton. Beberapa nilai awal akan di uji cobakan ke dalam metode-metode pendugaan parameter tersebut dan hasilnya akan disajikan dalam bentuk tabel. Kemudian pada percobaan selanjutnya, nilai-nilai tebakan awal yang gagal mendekati solusi sebenarnya akan dipakai sebagai tebakan awal dalam metode steepest descent maupun metode homotopi untuk menyelesaikan sistem persamaan tak liniernya, dan berikutnya parameter-parameter yang diperoleh dari metode stepest descent akan digunakan lagi sebagai tebakan awal baik untuk metode Newton maupun metode Gauss-Newton. 


\section{Metode Penelitian}

Bagian ini menjelaskan tentang teori yang akan digunakan, beserta langkah-langkah dalam melakukan pembahasan. Juga akan disajikan algoritma metode Newton, metode Gauss-Newton, metode steepest descent, dan metode homotopi untuk penyelesaian sistem persamaan tak linier.

\subsection{Regresi Tak Linier}

Jika diberikan data berpasangan $\left\{\left(x_{1}, y_{1}\right), \ldots,\left(x_{m}, y_{m}\right)\right\}$, model empiris untuk data ini dapat dinyatakan ke dalam bentuk model regresi dengan dua parameter berikut [4]:

$$
y=f\left(x ; \theta_{1}, \theta_{2}\right)+\epsilon
$$

Hubungan antara data $x_{i}$ dan $y_{i}$ dapat dituliskan sebagai

$$
y_{i}=f\left(x_{i} ; \theta_{1}, \theta_{2}\right)+\epsilon_{i}
$$

dengan $\epsilon_{i}$ adalah residu dari hasil pendugaan model dengan data ke- $i$, sedangkan $\theta_{1}$ dan $\theta_{2}$ adalah parameter-parameter tak diketahui yang harus diestimasi atau diduga. Persamaan (2) dikatakan sebagai regresi linier jika fungsi $f$ linier terhadap $\theta_{1}$ dan $\theta_{2}$, dan disebut regresi tak linier jika fungsi $f$ tak linier terhadap $\theta_{1}$ dan $\theta_{2}$. Berdasarkan Persamaan (2), dapat didefinisikan jumlah error kuadrat sebagai berikut

$$
s\left(\theta_{1}, \theta_{2}\right)=\sum_{i=1}^{m}\left[y_{i}-f\left(x_{i} ; \theta_{1}, \theta_{2}\right)\right]^{2}
$$

Untuk meminimalkan jumlah error kuadrat, Persamaan (4) diturunkan terhadap $\theta_{1}$ dan $\theta_{2}$, sehingga diperoleh

$$
\begin{gathered}
\frac{\partial s}{\partial \theta_{1}}=-2 \sum_{i=1}^{m}\left[y_{i}-f\left(x_{i} ; \theta_{1}, \theta_{2}\right)\right] \frac{\partial f\left(x_{i}, \theta_{1}, \theta_{2}\right)}{\partial \theta_{1}} \\
\frac{\partial s}{\partial \theta_{2}}=-2 \sum_{i=1}^{m}\left[y_{i}-f\left(x_{i} ; \theta_{1}, \theta_{2}\right)\right] \frac{\partial f\left(x_{i}, \theta_{1}, \theta_{2}\right)}{\partial \theta_{2}}
\end{gathered}
$$

dengan $\partial f / \partial \theta_{1}$ dan $\partial f / \partial \theta_{2}$ secara berturut-turut menyatakan turunan $f$ terhadap $\theta_{1}$ dan turunan $f$ terhadap $\theta_{2}$. Persamaan (4) minimum jika nilai $\theta_{1}$ dan $\theta_{2}$ memenuhi persamaan berikut

$$
\begin{aligned}
& \sum_{i=1}^{m}\left[y_{i}-f\left(x_{i} ; \theta_{1}, \theta_{2}\right)\right] \frac{\partial f\left(x_{i}, \theta_{1}, \theta_{2}\right)}{\partial \theta_{1}}=0 \\
& \sum_{i=1}^{m}\left[y_{i}-f\left(x_{i} ; \theta_{1}, \theta_{2}\right)\right] \frac{\partial f\left(x_{i}, \theta_{1}, \theta_{2}\right)}{\partial \theta_{2}}=0 .
\end{aligned}
$$

Nilai $\theta_{1}$ dan $\theta_{2}$ pada Persamaan (7) dapat diperoleh dengan menyelesaikan sistem persamaan tersebut secara simultan. Karena sistem Persamaan (7) tak linier, maka untuk menentukan $\theta_{1}$ dan 
$\theta_{2}$ dapat digunakan cara-cara penyelesaian sistem persamaan taklinier, diantaranya dengan metode Newton, metode Gauss-Newton, metode steepest descent, atau metode homotopi. Sistem Persamaan (7) dapat ditulis secara ringkas menjadi

$$
\begin{aligned}
& F_{1}\left(x_{i}, y_{i} ; \theta_{1}, \theta_{2}\right)=0 \\
& F_{2}\left(x_{i}, y_{i}, \theta_{1}, \theta_{2}\right)=0
\end{aligned}
$$

dengan

$$
F_{1}\left(x_{i}, y_{i} ; \theta_{1}, \theta_{2}\right)=\sum_{i=1}^{m}\left[y_{i}-f\left(x_{i} ; \theta_{1}, \theta_{2}\right)\right] \frac{\partial f\left(x_{i}, \theta_{1}, \theta_{2}\right)}{\partial \theta_{1}}
$$

dan

$$
F_{2}\left(x_{i}, y_{i} ; \theta_{1}, \theta_{2}\right)=\sum_{i=1}^{m}\left[y_{i}-f\left(x_{i} ; \theta_{1}, \theta_{2}\right)\right] \frac{\partial f\left(x_{i}, \theta_{1}, \theta_{2}\right)}{\partial \theta_{2}} \text {. }
$$

Matrik Jacobian dari $F_{1}\left(x_{i}, y_{i} ; \theta_{1}, \theta_{2}\right)$ dan $F_{2}\left(x_{i}, y_{i} ; \theta_{1}, \theta_{2}\right)$ sangat penting dalam melakukan perhitungan iterasi pada metode Newton, yaitu

$$
J=\left[\begin{array}{ll}
F_{1 \theta_{1}} & F_{1 \theta_{2}} \\
F_{2 \theta_{1}} & F_{2 \theta_{2}}
\end{array}\right]
$$

dengan $F_{1 \theta_{j}}=\frac{\partial F_{1}}{\partial_{\theta_{j}}}$ dan $F_{2 \theta_{j}}=\frac{\partial F_{2}}{\partial_{\theta_{j}}}, j=1,2$.

\subsection{Metode Newton}

Metode Newton untuk penyelesaian sistem persamaan tak linier sebagaimana yang terdapat dalam [2] dapat dinyatakan dalam bentuk algoritma berikut:

\section{Algoritma 1. Metode Newton untuk Penyelesaian Sistem Persamaan}

Metode Newton digunakan untuk mencari solusi dari sistem persamaan tak linier $\boldsymbol{F}(\boldsymbol{x})=\mathbf{0}$ dengan nilai awal $x^{\mathbf{0}}=\left(\boldsymbol{x}_{1}^{\mathbf{0}}, \ldots, \boldsymbol{x}_{\boldsymbol{n}}^{\mathbf{0}}\right)$, dimana $\boldsymbol{x}=\left(\boldsymbol{x}_{1}, \ldots, \boldsymbol{x}_{\boldsymbol{n}}\right)$ dan $\boldsymbol{F}=\left(\boldsymbol{f}_{1}(\boldsymbol{x}), \ldots, \boldsymbol{f}_{\boldsymbol{n}}(\boldsymbol{x})\right)$.

Input nilai awal $\boldsymbol{x}^{\mathbf{0}}=\left(\boldsymbol{x}_{\mathbf{1}}^{\mathbf{0}}, \ldots, \boldsymbol{x}_{\boldsymbol{n}}^{\mathbf{0}}\right)$; toleransi TOL; banyak iterasi maksimal $N$.

Output Solusi aproksimasi $\boldsymbol{x}=\left(x_{1}, \ldots, x_{n}\right)$ atau pesan bahwa toleransi TOL sudah dilampaui.

Step $1 \quad$ Atur $k=1$.

Step 2 While $(k \leq N)$ lakukan step 3-5.

Step 3 Hitung

$$
\boldsymbol{x}^{k}=\boldsymbol{x}^{k-1}-\left[\boldsymbol{J}\left(\boldsymbol{x}^{k-1}\right)\right]^{-1} \boldsymbol{F}\left(\boldsymbol{x}^{k-1}\right)
$$

dengan $\boldsymbol{J}$ adalah matriks jacobian dari fungsi $\boldsymbol{F}$.

Step $4 \quad$ Jika $\left\|\boldsymbol{x}^{k}-\boldsymbol{x}^{k-1}\right\|<$ TOL maka OUTPUT( $\boldsymbol{x}$ )

Prosedur berhasil

Stop

Step $5 \quad$ Atur $k=k+1$ 
Step 6 OUTPUT('iterasi maksimal sudah dilampaui');

(prosedur tidak menghasilkan solusi yang diharapkan)

\subsection{Metode Gauss-Newton}

Metode Gauss-Newton untuk pendugaan parameter model regresi tak linier (2) sebagaimana yang terdapat dalam [7] dapat diperoleh dengan melakukan pelinieran terhadap fungsi $f$ berdasarkan dalam [4] menjadi:

$$
\begin{aligned}
f^{k}\left(x ; \theta_{1}^{k}, \theta_{2}^{k}\right) & \approx f^{k-1}\left(x ; \theta_{1}^{k-1}, \theta_{2}^{k-1}\right)+\left[f_{\theta_{1}-1}^{k-1}\left(x ; \theta_{1}^{k-1}, \theta_{2}^{k-1}\right)\right]\left(\theta_{1}^{k}-\theta_{1}^{k-1}\right) \\
& +\left[f_{\theta_{2}}^{k-1}\left(x ; \theta_{1}^{k-1}, \theta_{2}^{k-1}\right)\right]\left(\theta_{2}^{k}-\theta_{2}^{k-1}\right), \quad k=1,2, \ldots
\end{aligned}
$$

fungsi $f_{\theta_{1}}^{k-1}, f_{\theta_{2}}^{k-1}$ pada Persamaan (10) adalah

$$
\left.\frac{\partial f\left(x, \theta_{1}, \theta_{2}\right)}{\partial \theta_{1}}\right|_{\substack{\theta_{1}=\theta_{1}^{k-1} \\ \theta_{2}=\theta_{2}^{k-1}}} \quad \text { dan }\left.\quad \frac{\partial f\left(x ; \theta_{1}, \theta_{2}\right)}{\partial \theta_{2}}\right|_{\substack{\theta_{1}=\theta_{1}^{k-1} \\ \theta_{2}=\theta_{2}^{k-1}}} .
$$

Berikutnya dengan mensubstitusikan bagian kanan dari (10) pada $f$ dalam Persamaan (2), diperoleh

$$
\begin{gathered}
y=f^{k-1}\left(x ; \theta_{1}^{k-1}, \theta_{2}^{k-1}\right)+\left[f_{\theta_{1}}^{k-1}\left(x ; \theta_{1}^{k-1}, \theta_{2}^{k-1}\right)\right]\left(\theta_{1}^{k}-\theta_{1}^{k-1}\right) \\
+\left[f_{\theta_{2}}^{k-1}\left(x ; \theta_{1}^{k-1}, \theta_{2}^{k-1}\right)\right]\left(\theta_{2}^{k}-\theta_{2}^{k-1}\right)+\epsilon .
\end{gathered}
$$

Jika setiap data ke- $i$ disubstitusikan pada Persamaan (11) diperoleh

$$
\begin{gathered}
y_{1}=f^{k-1}\left(x_{1} ; \theta_{1}^{k-1}, \theta_{2}^{k-1}\right)+\left[f_{\theta_{1}}^{k-1}\left(x_{1} ; \theta_{1}^{k-1}, \theta_{2}^{k-1}\right)\right]\left(\theta_{1}^{k}-\theta_{1}^{k-1}\right) \\
+\left[f_{\theta_{2}}^{k-1}\left(x_{1} ; \theta_{1}^{k-1}, \theta_{2}^{k-1}\right)\right]\left(\theta_{2}^{k}-\theta_{2}^{k-1}\right)+\epsilon_{1} \\
y_{2}=f^{k-1}\left(x_{2} ; \theta_{1}^{k-1}, \theta_{2}^{k-1}\right)+\left[f_{\theta_{1}}^{k-1}\left(x_{2} ; \theta_{1}^{k-1}, \theta_{2}^{k-1}\right)\right]\left(\theta_{1}^{k}-\theta_{1}^{k-1}\right) \\
+\left[f_{\theta_{2}}^{k-1}\left(x_{2} ; \theta_{1}^{k-1}, \theta_{2}^{k-1}\right)\right]\left(\theta_{2}^{k}-\theta_{2}^{k-1}\right)+\epsilon_{2} \\
\vdots \\
y_{m}=f^{k-1}\left(x_{m} ; \theta_{1}^{k-1}, \theta_{2}^{k-1}\right)+\left[f_{\theta_{1}}^{k-1}\left(x_{m} ; \theta_{1}^{k-1}, \theta_{2}^{k-1}\right)\right]\left(\theta_{1}^{k}-\theta_{1}^{k-1}\right) \\
+\left[f_{\theta_{2}}^{k-1}\left(x_{m} ; \theta_{1}^{k-1}, \theta_{2}^{k-1}\right)\right]\left(\theta_{2}^{k}-\theta_{2}^{k-1}\right)+\epsilon_{m}
\end{gathered}
$$

Selanjutnya untuk meringkas penulisan, masing-masing $f^{k-1}\left(x_{i} ; \theta_{1}^{k-1}, \theta_{2}^{k-1}\right)$, $f_{\theta_{1}}^{k-1}\left(x_{m} ; \theta_{1}^{k-1}, \theta_{2}^{k-1}\right)$ dan $f_{\theta_{2}}^{k-1}\left(x_{m} ; \theta_{1}^{k-1}, \theta_{2}^{k-1}\right)$ ditulis sebagai $f_{i}^{k-1}, f_{\theta_{1}, i}^{k-1}$ dan $f_{\theta_{2}, i}^{k-1}, i=$ $1, \ldots, m$. Sehingga sistem Persamaan (12) bisa dituliskan menjadi

$$
\left[\begin{array}{c}
y_{1} \\
y_{2} \\
\vdots \\
y_{m}
\end{array}\right]=\left[\begin{array}{c}
f_{1}^{k-1} \\
f_{2}^{k-1} \\
\vdots \\
f_{m}^{k-1}
\end{array}\right]+\left[\begin{array}{cc}
f_{\theta_{1}, 1}^{k-1} & f_{\theta_{2}, 1}^{k-1} \\
f_{\theta_{1}, 2}^{k-1} & f_{\theta_{2}, 2}^{k-1} \\
\vdots & \vdots \\
f_{\theta_{1}, m}^{k-1} & f_{\theta_{2}, m}^{k-1}
\end{array}\right]\left[\begin{array}{l}
\theta_{1}^{k}-\theta_{1}^{k-1} \\
\theta_{2}^{k}-\theta_{2}^{k-1}
\end{array}\right]+\left[\begin{array}{c}
\epsilon_{1} \\
\epsilon_{2} \\
\vdots \\
\epsilon_{m}
\end{array}\right],
$$

atau 


$$
\left[\begin{array}{c}
\epsilon_{1} \\
\epsilon_{2} \\
\vdots \\
\epsilon_{m}
\end{array}\right]=\left[\begin{array}{c}
y_{1} \\
y_{2} \\
\vdots \\
y_{m}
\end{array}\right]-\left[\begin{array}{c}
f_{1}^{k-1} \\
f_{2}^{k-1} \\
\vdots \\
f_{m}^{k-1}
\end{array}\right]-\left[\begin{array}{cc}
f_{\theta_{1}, 1}^{k-1} & f_{\theta_{2}, 1}^{k-1} \\
f_{\theta_{1}, 2}^{k-1} & f_{\theta_{2}, 2}^{k-1} \\
\vdots & \vdots \\
f_{\theta_{1}, m}^{k-1} & f_{\theta_{2}, m}^{k-1}
\end{array}\right]\left[\begin{array}{l}
\theta_{1}^{k}-\theta_{1}^{k-1} \\
\theta_{2}^{k}-\theta_{2}^{k-1}
\end{array}\right]
$$

Persamaan (14) bisa ditulis ulang menjadi

$$
\left[\begin{array}{c}
\epsilon_{1} \\
\epsilon_{2} \\
\vdots \\
\epsilon_{m}
\end{array}\right]=\left[\begin{array}{c}
y_{1}-f_{1}^{k-1} \\
y_{1}-f_{2}^{k-1} \\
\vdots \\
y_{1}-f_{m}^{k-1}
\end{array}\right]-\left[\begin{array}{cc}
f_{\theta_{1}, 1}^{k-1} & f_{\theta_{2}, 1}^{k-1} \\
f_{\theta_{1}, 2}^{k-1} & f_{\theta_{2}, 2}^{k-1} \\
\vdots & \vdots \\
f_{\theta_{1}, m}^{k-1} & f_{\theta_{2}, m}^{k-1}
\end{array}\right]\left[\begin{array}{c}
\theta_{1}^{k} \\
\theta_{2}^{k}
\end{array}\right]+\left[\begin{array}{cc}
f_{\theta_{1}, 1}^{k-1} & f_{\theta_{2}, 1}^{k-1} \\
f_{\theta_{1}, 2}^{k-1} & f_{\theta_{2}, 2}^{k-1} \\
\vdots & \vdots \\
f_{\theta_{1}, m}^{k-1} & f_{\theta_{2}, m}^{k-1}
\end{array}\right]\left[\begin{array}{c}
\theta_{1}^{k-1} \\
\theta_{2}^{k-1}
\end{array}\right]
$$

Dengan memisalkan

$$
E=\left[\begin{array}{c}
\epsilon_{1} \\
\epsilon_{2} \\
\vdots \\
\epsilon_{m}
\end{array}\right], \quad C=\left[\begin{array}{c}
y_{1}-f_{1}^{k-1} \\
y_{2}-f_{2}^{k-1} \\
\vdots \\
y_{m}-f_{m}^{k-1}
\end{array}\right], \quad A=\left[\begin{array}{cc}
f_{\theta_{1}, 1}^{k-1} & f_{\theta_{2}, 1}^{k-1} \\
f_{\theta_{1}, 2}^{k-1} & f_{\theta_{2}, 2}^{k-1} \\
\vdots & \vdots \\
f_{\theta_{1}, m}^{k-1} & f_{\theta_{2}, m}^{k-1}
\end{array}\right], \quad \Theta^{k}=\left[\begin{array}{c}
\theta_{1}^{k} \\
\theta_{2}^{k}
\end{array}\right], \quad \Theta^{k-1}=\left[\begin{array}{c}
\theta_{1}^{k-1} \\
\theta_{2}^{k-1}
\end{array}\right],
$$

di dapat

$$
E=B-A \Theta^{k}, \quad \text { dengan } B=C+A \Theta^{k-1} .
$$

Persamaan (17) minimum jika

$$
\|E\|=\left\|B-\mathrm{A} \Theta^{k}\right\|
$$

Persamaan (18) juga minimum, proses ini membawa pada solusi masalah kuadrat terkecil dari $\left(B-A \Theta^{k}=\mathbf{0}\right)[8]$, yaitu

$$
\Theta^{k}=\left[A^{\prime} A\right]^{-1}\left[A^{\prime} B\right],
$$

dimana $A^{\prime}$ adalah transpose dari $A$.

Untuk memperoleh $\Theta^{k}$ yang optimal, perhitungan Persamaan (19) dilakukan secara berulang, sampai kondisi pada persamaan (20) berikut terpenuhi

$$
\left\|\Theta^{k}-\Theta^{k-1}\right\| \leq \varepsilon
$$

dengan $\varepsilon$ adalah batas toleransi yang diberikan.

\section{Algoritma 2. Metode Gauss-Newton untuk Pendugaan Parameter Regresi Tak Linier}

Menduga parameter $\boldsymbol{\theta}_{\mathbf{1}}$ dan $\boldsymbol{\theta}_{\mathbf{2}}$ untuk persamaan regresi tak linier $\boldsymbol{y}=\boldsymbol{f}\left(\boldsymbol{x} ; \boldsymbol{\theta}_{\mathbf{1}}, \boldsymbol{\theta}_{\mathbf{2}}\right)$.

Input Nilai awal $\left(\theta_{1}^{0}, \theta_{2}^{0}\right)$, data $\left(x_{i}, y_{i}\right)$, banyak data $m$; toleransi TOL; banyak iterasi maksimal $N$.

Output Parameter aproksimasi $\left(\theta_{1}, \theta_{2}\right)$ atau pesan bahwa banyak iterasi maksimal sudah dilampaui.

Step $1 \quad$ Atur $k=2$

Step 2 while $k \leq N$ lakukan step 3-6 berikut 
Step 3 Hitung $A$ dan $B$ sebagaimana yang telah didefinisikan pada Persamaan (16) dan (17).

Step 4 Hitung $\Theta^{k}=\left[A^{\prime} A\right]^{-1} A^{\prime} B$

Step 5 Jika $\left\|\Theta^{k}-\Theta^{k-1}\right\| \leq T O L$ maka

Hentikan iterasi

Output $\left(\theta_{1}, \theta_{2}\right)$

Stop

Step 6 Atur $k=k+1$

Step 7 output ('maksimum iterasi telah dicapai')

(prosedur tidak menghasilkan solusi yang diharapkan)

stop

\subsection{Metode steepest descent}

Metode steepest descent untuk penyelesaian sistem Persamaan (8) sebagaimana yang terdapat dalam [2] dapat dinyatakan dalam bentuk algoritma berikut:

\section{Algoritma 3. Metode Steepest Descent}

Metode ini digunakan untuk mencari nilai hampiran $\boldsymbol{p}$ pada masalah meminimalkan

Dengan $g(x)=f_{1}^{2}+\cdots+f_{n}^{2}$ nilai awal $x^{0}$.

$$
g(p)=\min _{x \in \mathbb{R}^{n}} g(x)
$$

Input Banyaknya peubah $(n)$; nilai tebakan awal $x=\left(x_{1}^{0}, \ldots, x_{n}^{0}\right)^{\prime}$; batas toleransi kesalahan TOL; banyaknya iterasi maksimal $N$.

Output Solusi aproksimasi $x=\left(x_{1}, \ldots, x_{n}\right)^{\prime}$ atau pesan kesalahan.

Step 1 Atur $k=1$

Step 2 while $(k \leq N)$ lakukan step 3-15:

Step 3 atur $g_{1}=g\left(x_{1}, \ldots, x_{n}\right)$

$z=\left\|\nabla g\left(x_{1}, \ldots, x_{n}\right)\right\|_{2}$

Step 4 Jika $z_{0}=0$ maka Output('Zero gradient')

Output $\left(x_{1}, \ldots, x_{n}, g_{1}\right)$

Stop

Step 5 Atur $z=z / z_{0}$

$\alpha_{1}=0$

$\alpha_{2}=0$

$\alpha_{3}=g\left(x-\alpha_{3} z\right)$

Step 6 While $\left(g_{3} \geq g_{1}\right)$ lakukan step 7 dan 8

Step $7 \quad$ Atur $\alpha_{3}=\alpha_{3} / 2$

$\begin{array}{ll} & g_{3}=g\left(x-\alpha_{3} z\right) \\ \text { Step } 8 & \text { If } \alpha_{3}<\frac{T O L}{2} \text { maka }\end{array}$

Output('tidak ada perbaikan')

Output $\left(x_{1}, \ldots, x_{n}, g_{1}\right)$

Stop 
$\begin{array}{ll}\text { Step } 9 & \text { Atur } \alpha_{2}=\frac{\alpha_{3}}{2} \\ & g_{2}=g\left(x-\alpha_{2} z\right) \\ \text { Step 10 } & \text { Atur } h_{1}=\frac{g_{2}-g_{1}}{\alpha_{2}}\end{array}$

Step 10 Atur $h_{1}=\frac{g_{2}-g_{1}}{\alpha_{2}}$

$h_{2}=\frac{g_{3}-g_{2}}{\alpha_{3}-\alpha_{2}}$

$h_{3}=\frac{h_{2}-h_{1}}{\alpha_{3}}$

(Catatan: Metode Newton divided difference digunakan untuk menentukan interpolasi kuadratik $P(\alpha)=g_{1}+h_{1} \alpha+h_{3} \alpha\left(\alpha-\alpha_{2}\right)$ yang menginterpolasi $h(\alpha)$ pada $\alpha=0, \alpha=\alpha_{2}, \alpha=\alpha_{3}$.)

Step 11 Atur $\alpha_{0}=0.5\left(\alpha_{2}-\frac{h_{1}}{h_{3}}\right)$

$$
g_{0}=g\left(x-\alpha_{0} z\right)
$$

Step 12 tentukan $\alpha$ dari $\left\{\alpha_{0}, \alpha_{3}\right\}$ so that $g=g(x-\alpha z)=\min \left\{g_{0}, g_{3}\right\}$

Step 13 atur $x=x-\alpha z$

Step 14 jika $\left|g-g_{1}\right|<T O L$ maka

Output $\left(x_{1}, \ldots, x_{n}, g\right)$

Stop

Step 15 Atur $k=k+1$

Step 16 output ('maksimum iterasi telah dicapai')

Prosedur tidak sukses alias gagal

stop

\subsection{Metode Homotopi}

Metode homotopi untuk penyelesaian sistem persamaan tak linier (8) sebagaimana yang terdapat dalam [2] dapat dinyatakan dalam bentuk algoritma berikut:

\section{Algoritma 4. Metode Homotopi}

Tujuan untuk mencari solusi hampiran dari system persamaan taklinier $\boldsymbol{F}(\boldsymbol{\Theta})=\mathbf{0}$ dengan $\boldsymbol{F}=\left(\boldsymbol{F}_{\mathbf{1}}, \boldsymbol{F}_{\mathbf{2}}\right)$ dan $\Theta=\left(\boldsymbol{\theta}_{1}, \boldsymbol{\theta}_{2}\right)$ nilai tebakan awal $\boldsymbol{\Theta}^{\mathbf{0}}=\left(\boldsymbol{\theta}_{\mathbf{1}}^{\mathbf{0}}, \boldsymbol{\theta}_{2}^{\mathbf{0}}\right)$.

Input nilai awal $\Theta^{\mathbf{0}}=\left(\boldsymbol{\theta}_{1}^{\mathbf{0}}, \boldsymbol{\theta}_{2}^{\mathbf{0}}\right)$.

output Solusi aproksimasi $\boldsymbol{\Theta}=\left(\boldsymbol{\theta}_{1}, \boldsymbol{\theta}_{2}\right)$

Step 1 Atur $h=\frac{1}{N}$, dengan $N$ adalah bilangan bulat positif sehingga $0<h<1$.

$b=-h F(\Theta)$

Step 2 untuk $i=0,1, \ldots,(N-1)$ lakukan Langkah 3-7, yaitu

Step 3

atur $A=J\left(\left[\begin{array}{l}\theta_{1}^{i} \\ \theta_{2}^{i}\end{array}\right]\right)$

selesaikan system linier $A k_{1}=b$

Step 4

atur $A=J\left(\left[\begin{array}{l}\theta_{1}^{i} \\ \theta_{2}^{i}\end{array}\right]+\frac{1}{2} k_{1}\right)$

selesaikan system linier $A k_{2}=b$

Step 5

$$
\text { atur } A=J\left(\left[\begin{array}{c}
\theta_{1}^{i} \\
\theta_{2}^{i}
\end{array}\right]+\frac{1}{2} k_{2}\right)
$$




$$
\begin{array}{lll} 
& \text { selesaikan system linier } A k_{3}=b \\
& & \text { atur } A=J\left(\left[\begin{array}{l}
\theta_{1}^{i} \\
\theta_{2}^{i}
\end{array}\right]+k_{3}\right) \\
& \text { Step } 7 & \text { selesaikan system linier } A k_{4}=b \\
\text { Step } 8 & \text { atur }\left[\begin{array}{l}
\theta_{1}^{i+1} \\
\theta_{2}^{i+1}
\end{array}\right]=\left[\begin{array}{l}
\theta_{1}^{i} \\
\theta_{2}^{i}
\end{array}\right]+\frac{k_{1}+2 k_{2}+2 k_{3}+k_{4}}{6} \\
& \begin{array}{l}
\text { output }\left(\theta_{1}, \theta_{2}\right) \\
\text { stop }
\end{array}
\end{array}
$$

\section{Diskusi dan Pembahasan}

Pada bagian ini dibahas penerapan metode-metode penyelesaian sistem persamaan taklinier (8) untuk menentukan parameter dari model regresi tak linier (2).

\subsection{Percobaan 1}

Sebagai contoh, akan dilakukan pendugaan parameter $\theta_{1}$ dan $\theta_{2}$ dari model regresi taklinier berikut

$$
f\left(x ; \theta_{1}, \theta_{2}\right)=\theta_{1}\left(1-e^{-\theta_{2} x}\right)
$$

menggunakan data pada Tabel 1 berikut:

Tabel 1. Data hasil observasi

\begin{tabular}{|l|l|l|l|l|l|}
\hline $\boldsymbol{x}$ & 0.25 & 0.75 & 1.25 & 1.75 & 2.25 \\
\hline $\boldsymbol{y}$ & 0.28 & 0.57 & 0.68 & 0.74 & 0.79 \\
\hline
\end{tabular}

serta nilai awal untuk parameter $\theta_{1}^{0}$ dan $\theta_{2}^{0}$ (sumber: [4]).

Untuk melakukan pendugaan parameter model regresi tak linier (21) menggunakan Algoritma 1 (metode Newton), Algoritma 3 (metode steepest descent), Algoritma 4 (metode homotopi), terlebih dahulu didefinisikan jumlah error kuadrat berikut

$$
s\left(x_{i}, y_{i} ; \theta_{1}, \theta_{2}\right)=\sum_{i=1}^{5}\left[y_{i}-\theta_{1}\left(1-e^{-\theta_{2} x_{i}}\right)\right] .
$$

Agar $s\left(x_{i}, y_{i} ; \theta_{1}, \theta_{2}\right)$ minimum, dapat dikonstruksi sistem persamaan tak linier

$$
\begin{aligned}
& F_{1}\left(x_{i}, y_{i} ; \theta_{1}, \theta_{2}\right)=0 \\
& F_{2}\left(x_{i}, y_{i} ; \theta_{1}, \theta_{2}\right)=0
\end{aligned}
$$

dengan

$$
F_{1}\left(x_{i}, y_{i} ; \theta_{1}, \theta_{2}\right)=\frac{\partial s\left(x_{i}, y_{i} ; \theta_{1}, \theta_{2}\right)}{\partial \theta_{1}}, \quad F_{2}\left(x_{i}, y_{i} ; \theta_{1}, \theta_{2}\right)=\frac{\partial s\left(x_{i}, y_{i} ; \theta_{1}, \theta_{2}\right)}{\partial \theta_{2}}
$$

Selanjutnya parameter $\theta_{1}$ dan $\theta_{2}$ yang memenuhi sistem Persamaan (21) dapat dihitung menggunakan Algoritma 1, Algoritma 3, dan Algoritma 4. 
Untuk menentukan parameter $\theta_{1}$ dan $\theta_{2}$ menggunakan Algoritma (Gauss-Newton), dilakukan pelinieran Persamaan (21) sebagaimana pada Persamaan (10), sehingga diperoleh

$$
\begin{aligned}
f\left(x ; \theta_{1}^{k}, \theta_{2}^{k}\right) \approx & \theta_{1}^{k-1}\left(1-e^{-\theta_{2}^{k-1} x}\right)+\left(1-e^{-\theta_{2}^{k-1}}\right)\left(\theta_{1}^{k}-\theta_{1}^{k-1}\right) \\
& +\theta_{1}^{k-1} x e^{-\theta_{2}^{k-1} x}\left(\theta_{2}^{k}-\theta_{2}^{k-1}\right) .
\end{aligned}
$$

Berdasarkan persamaan (16) dan (17) dapat dikonstruksi matriks $A$ dan $C$ berikut:

$$
A=\left[\begin{array}{cc}
1-e^{-\theta_{2}^{k-1} x_{1}} & \theta_{1}^{k-1} x e^{-\theta_{2}^{k-1} x_{1}} \\
1-e^{-\theta_{2}^{k-1} x_{2}} & \theta_{1}^{k-1} x e^{-\theta_{2}^{k-1} x_{1}} \\
\vdots & \vdots \\
1-e^{-\theta_{2}^{k-1} x_{m}} & \theta_{1}^{k-1} x e^{-\theta_{2}^{k-1} x_{1}}
\end{array}\right], \quad C=\left[\begin{array}{c}
y_{1}-\theta_{1}^{k-1}\left(1-e^{-\theta_{2}^{k-1} x_{1}}\right) \\
y_{2}-\theta_{1}^{k-1}\left(1-e^{-\theta_{2}^{k-1} x_{2}}\right) \\
\vdots \\
y_{m}-\theta_{1}^{k-1}\left(1-e^{-\theta_{2}^{k-1} x_{m}}\right)
\end{array}\right] .
$$

Selanjutnya parameter $\theta_{1}^{k}$ dan $\theta_{2}^{k}$ menggunakan persamaan (19).

Berikut ini adalah tabel hasil pendugaan parameter Persamaan (21) menggunakan data pada Tabel 1 dan beberapa nilai awal dengan batas toleransi $\epsilon=1 \times 10^{-8}$.

Tabel 2. Konvergensi beberapa nilai awal dan metode pendugaan parameter terhadap solusi dari persamaan regresi $(21)$.

\begin{tabular}{c|cccccc}
\hline Percobaan & \multicolumn{7}{|c}{ Metode } \\
\cline { 2 - 7 } & $\theta_{1,0}$ & $\theta_{2,0}$ & Newton & $\begin{array}{c}\text { Gauss- } \\
\text { Newton }\end{array}$ & $\begin{array}{c}\text { Steepest } \\
\text { Descent }\end{array}$ & Homotopi \\
\hline 1 & 1 & 1 & sukses & sukses & sukses & sukses \\
& 1 & 2 & sukses & sukses & sukses & gagal \\
\hline 3 & 1 & 3 & gagal & sukses & sukses & gagal \\
4 & 2 & 1 & gagal & sukses & sukses & sukses \\
\hline 5 & 2 & 2 & sukses & sukses & sukses & gagal \\
6 & 2 & 3 & gagal & sukses & sukses & gagal \\
\hline 7 & 3 & 1 & gagal & sukses & sukses & sukses \\
8 & 3 & 2 & sukses & sukses & sukses & sukses \\
\hline 9 & 3 & 3 & sukses & sukses & sukses & sukses \\
10 & 10 & -10 & gagal & gagal & sukses & gagal \\
\hline 11 & -10 & 10 & gagal & gagal & gagal & gagal \\
12 & -100 & 100 & gagal & gagal & gagal & gagal \\
\hline 13 & 100 & -100 & gagal & gagal & gagal & gagal
\end{tabular}

Adapun perbandingan antara model regresi hasil pendugaan dengan data hasil observasi yang optimum dapat dilihat pada gambar berikut: 


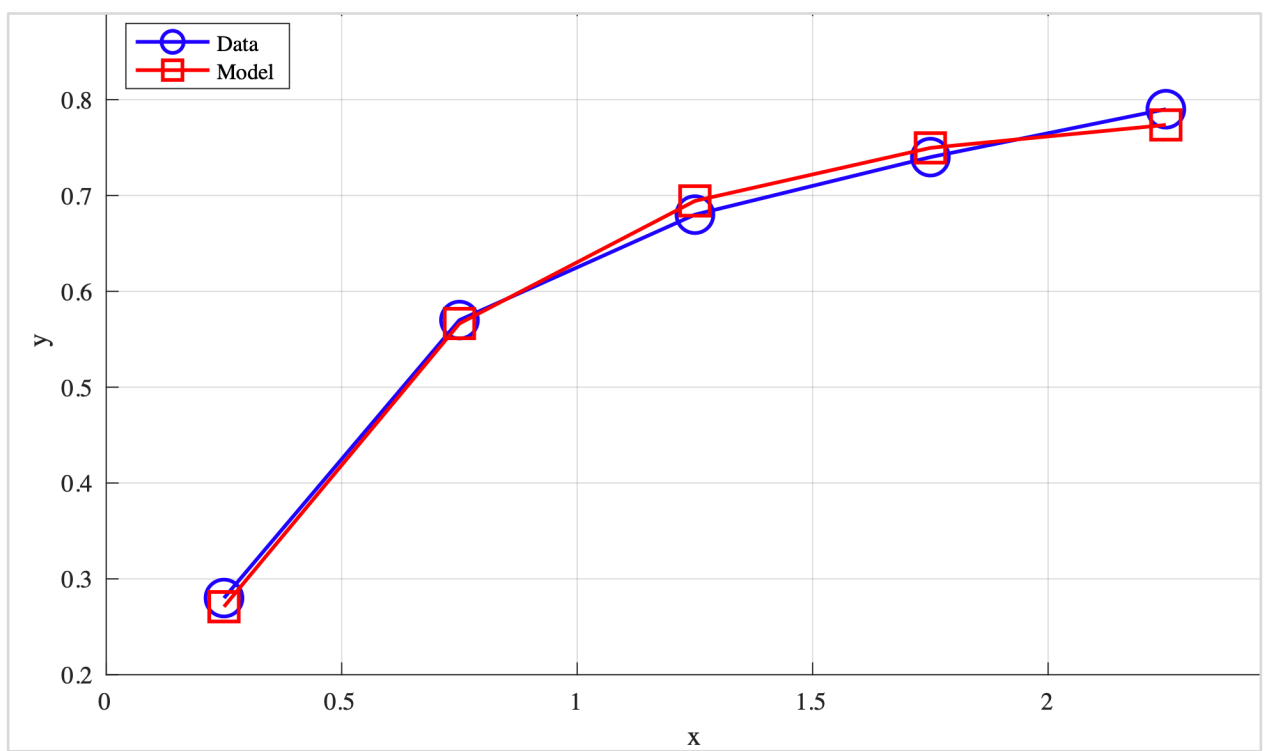

Gambar 1. Perbandingan antara model regresi hasil pendugaan parameter dengan data hasil observasi

\subsection{Percobaan 2}

Pada bagian ini, akan dilakukan pendugaan parameter $\theta_{1}$ dan $\theta_{2}$ dari model regresi taklinier dengan $f$ berikut:

$$
f\left(x ; \theta_{1}, \theta_{2}\right)=\theta_{1} e^{-\theta_{2} x}
$$

menggunakan data pada Tabel 3 berikut:

Tabel 3. Contoh data hasil observasi

\begin{tabular}{|c|c|c|c|c|c|c|}
\hline $\boldsymbol{x}$ & 1 & 2 & 3 & 4 & 5 & 6 \\
\hline $\boldsymbol{y}$ & 10 & 5.49 & 0.89 & -0.14 & -1.07 & 0.84 \\
\hline
\end{tabular}

serta nilai awal untuk parameter $\theta_{1}^{0}$ dan $\theta_{2}^{0}$ (sumber: [7]).

Untuk melakukan pendugaan parameter model regresi tak linier (26) menggunakan Algoritma 1 (metode Newton), Algoritma 3 (metode steepest descent), Algoritma 4 (metode homotopi), terlebih dahulu didefinisikan jumlah error kuadrat berikut

$$
s\left(x_{i}, y_{i} ; \theta_{1}, \theta_{2}\right)=\sum_{i=1}^{6}\left[y_{i}-\theta_{1} e^{-\theta_{2} x}\right] \text {. }
$$

Agar $s\left(x_{i}, y_{i} ; \theta_{1}, \theta_{2}\right)$ minimum, dapat konstruksi sistem persamaan tak linier

$$
\begin{aligned}
& F_{1}\left(x_{i}, y_{i} ; \theta_{1}, \theta_{2}\right)=0 \\
& F_{2}\left(x_{i}, y_{i} ; \theta_{1}, \theta_{2}\right)=0
\end{aligned}
$$

dengan

$$
F_{1}\left(x_{i}, y_{i} ; \theta_{1}, \theta_{2}\right)=\frac{\partial s\left(x_{i}, y_{i} ; \theta_{1}, \theta_{2}\right)}{\partial \theta_{1}}, \quad F_{2}\left(x_{i}, y_{i} ; \theta_{1}, \theta_{2}\right)=\frac{\partial s\left(x_{i}, y_{i} ; \theta_{1}, \theta_{2}\right)}{\partial \theta_{2}}
$$


Selanjutnya parameter $\theta_{1}$ dan $\theta_{2}$ yang memenuhi sistem Persamaan (27) dapat dihitung menggunakan Algoritma 1, Algoritma 3, dan Algoritma 4.

Untuk menentukan parameter $\theta_{1}$ dan $\theta_{2}$ menggunakan Algoritma (Gauss-Newton), dilakukan pelinieran Persamaan (26) sebagaimana pada Persamaan (10), sehingga diperoleh

$$
f\left(x ; \theta_{1}^{k}, \theta_{2}^{k}\right) \approx \theta_{1}^{k-1} e^{-\theta_{2}^{k-1} x}+e^{-\theta_{2}^{k-1} x}\left(\theta_{1}^{k}-\theta_{1}^{k-1}\right)+\theta_{1}^{k-1} x e^{-\theta_{2}^{k-1} x}\left(\theta_{2}^{k}-\theta_{2}^{k-1}\right) .
$$

Berdasarkan persamaan (16) dan (17) dapat dikonstruksi matriks $A$ dan $C$ berikut:

$$
A=\left[\begin{array}{cc}
e^{-\theta_{2}^{k-1} x_{1}} & \theta_{1}^{k-1} x e^{-\theta_{2}^{k-1} x_{1}} \\
e^{-\theta_{2}^{k-1} x_{2}} & \theta_{1}^{k-1} x e^{-\theta_{2}^{k-1} x_{2}} \\
\vdots & \vdots \\
e^{-\theta_{2}^{k-1} x_{m}} & \theta_{1}^{k-1} x e^{-\theta_{2}^{k-1} x_{m}}
\end{array}\right], \quad C=\left[\begin{array}{c}
y_{1}-\theta_{1}^{k-1} e^{-\theta_{2}^{k-1} x_{1}} \\
y_{2}-\theta_{1}^{k-1} e^{-\theta_{2}^{k-1} x_{2}} \\
\vdots \\
y_{m}-\theta_{1}^{k-1} e^{-\theta_{2}^{k-1} x_{m}}
\end{array}\right]
$$

Selanjutnya parameter $\theta_{1}^{k}$ dan $\theta_{2}^{k}$ menggunakan Persamaan (19).

Berikut ini adalah tabel hasil pendugaan parameter Persamaan (26) menggunakan data pada Tabel 3 dan beberapa nilai awal dengan batas toleransi $\epsilon=1 \times 10^{-8}$.

Tabel 4. Konvergensi beberapa nilai awal dan metode pendugaan parameter terhadap solusi persamaan regresi (26).

\begin{tabular}{c|cccccc}
\hline $\begin{array}{c}\text { Percobaan } \\
2\end{array}$ & \multicolumn{7}{c}{ Metode } & & Homotopi \\
\cline { 2 - 7 } & $\theta_{1,0}$ & $\theta_{2,0}$ & Newton & $\begin{array}{c}\text { Gauss- } \\
\text { Newton }\end{array}$ & $\begin{array}{c}\text { Steepest } \\
\text { Descent }\end{array}$ & \\
\hline 1 & 25 & 0.9 & sukses & sukses & sukses & sukses \\
2 & 1 & 1 & gagal & gagal & gagal & gagal \\
\hline 3 & 1 & 2 & gagal & gagal & gagal & gagal \\
4 & 1 & 3 & gagal & gagal & gagal & gagal \\
\hline 5 & 2 & 1 & gagal & gagal & gagal & gagal \\
6 & 2 & 2 & gagal & gagal & gagal & gagal \\
\hline 7 & 2 & 3 & gagal & gagal & gagal & gagal \\
8 & 3 & 1 & gagal & gagal & gagal & gagal \\
\hline 9 & 3 & 2 & gagal & gagal & gagal & gagal \\
10 & 3 & 3 & gagal & gagal & gagal & gagal \\
\hline 11 & 10 & -10 & gagal & gagal & gagal & gagal \\
12 & -10 & 10 & gagal & gagal & gagal & gagal \\
\hline 13 & -100 & 100 & gagal & gagal & gagal & gagal \\
14 & 100 & -100 & gagal & gagal & gagal & Gagal \\
\hline 15 & 0.1848 & 0.1848 & sukses & sukses & sukses & sukses \\
16 & 0.8852 & 0.9133 & Sukses & Sukses & Sukses & Sukses \\
\hline 17 & 0.9037 & 0.9037 & Sukses & Sukses & Sukses & Sukses \\
18 & 0.4799 & 0.4799 & Sukses & Sukses & Sukses & Sukses \\
\hline 19 & 0.1078 & 0.9063 & Sukses & Sukses & Sukses & Sukses \\
20 & -49.4456 & 0.0261 & Sukses & Sukses & Sukses & Sukses \\
\hline 21 & -110.3384 & 0.6503 & sukses & sukses & sukses & sukses \\
& & & & & & \\
\hline
\end{tabular}


Pada percobaan ke-15 sampai ke-19, nilai awal dibangkitkan menggunakan bilangan random antara 0 sampai 1. Sedangkan pada percobaan ke-20 digunakan bilangan random antara -50 sampai 50 dan pada percobaan ke-21 digunakan bilangan random antara -500 sampai 500.

\section{Simpulan}

Kesimpulan yang diperoleh dari beberapa kali percobaan yang telah dilakukan diatas adalah penggunaan metode iterasi, baik metode Newton maupun Gauss-Newton memerlukan tebakan awal yang baik agar solusi yang diharapkan bisa diperoleh. Tetapi bagaimana cara mendapatkan tebakan awal yang baik itu tidak mudah, karena sampai saat ini belum ada algoritma maupun metode yang bisa menentukan nilai tebakan awal yang baik.

Konvergensi metode tidak bergantung pada jauh atau dekatnya nilai awal dengan solusi, tetapi bergantung pada nilai awal yang menyebabkan nilai-nilai pada matrik Jacobi berhingga. Jika nilai awal yang dipilih menyebabkan nilai-nilai pada matrik Jacobi tak berhingga, maka solusinya tidak ada.

\section{Daftar Pustaka}

[1] H. Bunke, "18 Parameter estimation in nonlinear regression models," Handb. Stat., vol. 1, pp. 593-615, 1980.

[2] R. L. Burden and J. D. Faires, "Numerical analysis 8th ed," Thomson Brooks/Cole, 2005.

[3] T. L. Zhang, "Solving non-linear equation based on steepest descent method," Proc. - 4th Int. Conf. Inf. Comput. ICIC 2011, pp. 216-218, 2011, doi: 10.1109/ICIC.2011.107.

[4] S. C. Chapra and R. P. Canale, "Numerical methods for engineers," pp. 722-733, 1998.

[5] D. Constales, G. S. Yablonsky, D. R. D’hooge, J. W. Thybaut, and G. B. Marin, “Experimental Data Analysis," Adv. Data Anal. Model. Chem. Eng., pp. 285-306, 2017, doi: 10.1016/b978-0-444-59485-3.00009-6.

[6] H.-H. Huang and S.-Y. Huang, "Nonlinear regression analysis," Int. Encycl. Educ., pp. 339$346,2010$.

[7] W. H. Lai, S. L. Kek, and K. G. Tay, "Solving Nonlinear Least Squares Problem Using Gauss-Newton Method," Int. J. Innov. Sci. Eng. Technol., vol. 4, no. 1, pp. 258-262, 2017.

[8] B. Jacob, Linear Algebra. W. H, Freeman And Company, New York. 1990. 